\title{
PROGRAM HI-LINK PERBAIKAN TEKNOLOGI PENGOLAHAN JAGUNG DI UD ANNISA, WONOSOBO
}

\author{
Nur Aini $^{\# 1}$, Hidayah Dwiyanti ${ }^{\# 2}$, Retno Setyawati ${ }^{\# 3}$ Budi Sustriawan $^{\# 4}$ \\ \#Program Studi Ilmu dan Teknologi Pangan Universitas Jenderal Soedirman \\ Jalan Dr. Soeparno, Purwokerto \\ ${ }^{1}$ email.nur.aini@unsoed.ac.id \\ ${ }^{2}$ email.hidayah.dwiyantilunsoed.ac.id \\ ${ }^{3}$ email.retno.setyawati@unsoed.ac.id \\ ${ }^{4}$ email.budi.sustriawan@unsoed.ac.id
}

\begin{abstract}
Abstrak
Pengembangan produk pangan berbasis jagung memiliki peluang yang menjanjikan, sehingga pemerintah daerah Kabupaten Wonosobo saat ini menginisiasi program untuk pengembangan diversifikasi pangan berbasis jagung. Program ini diharapkan dapat meningkatkan peran UKM pengolahan jagung sehingga semakin mantap berproduksi dengan adanya aneka macam varian produk. Program Hi-Link ditujukan untuk penerapan teknologi pengolahan pangan berbasis jagung yang dibutuhkan oleh industri, terutama untuk menerapkan penggunaan kabinet pengering, ayakan getar (siever shaker) dan ekstruder untuk mencetak getas. Metode yang diterapkan adalah diseminasi informasi teknologi, penerapan teknologi dan pelatihan dan penyediaan alat produksi untuk mendukung penerapan teknologi. Luaran program adalah alat dan mesin pengolahan pangan dari jagung untuk meningkatkan kapasitas produksi yaitu berupa pengering kabinet, ayakan getar dan ekstruder serta perbaikan teknologi pengolahan getas. Kegiatan Hi Link memberikan dampak positif pada meningkatnya kapasitas produksi beras jagung instan dari 150 menjadi $300 \mathrm{~kg}$ per bulan, tepung jagung dari 50 kg menjadi $200 \mathrm{~kg}$ per bulan dan getas dari $150 \mathrm{~kg}$ menjadi $400 \mathrm{~kg}$ per bulan.
\end{abstract}

Kata Kunci — Beras jagung instan, tepung jagung, pengeringan, pengayakan, Wonosobo

\section{PENDAHULUAN}

Jagung mempunyai peranan yang cukup besar dalam perekonomian dan ketahanan pangan di Wonosobo. Selama ini belum ada perhatian khusus dari pemerintah Kabupaten Wonosobo dalam hal pengolahan jagung menjadi produk-produk pangan. Padahal jagung merupakan sumber karbohidrat setara beras yang keberadaannya dapat menggantikan sebagian kebutuhan beras. Jagung juga dapat diolah menjadi tepung, dan tepung jagung dapat digunakan untuk mengganti sebagian atau keseluruhan tepung terigu pada produk pangan [1].

Pengembangan produk pangan berbasis jagung memiliki peluang yang menjanjikan, sehingga pemerintah daerah Kabupaten Wonosobo saat ini menginisiasi program untuk pengembangan diversivikasi pangan berbasis jagung. Konsep pengembangan ini sejalan dengan program yang sedang digiatkan oleh Pemerintah Daerah Kabupaten Wonosobo yaitu menciptakan satu produk unggulan untuk satu wilayah "One District, One Product $(O D O P)$ ". Diharapkan dengan adanya diversifikasi produk maka nilai jual dan nilai ekonomi jagung akan semakin meningkat. UKM yang bergerak di bidang pengolahan jagung juga akan semakin mantap berproduksi dengan adanya aneka macam varian produk.

Pada program diversifikasi pangan, jagung dapat diolah menjadi tepung karena tepung dapat lebih luas digunakan untuk berbagai macam bahan makanan, penyimpanan lebih mudah dan umur simpan lebih lama, serta adanya defisiensi beberapa zat gizi yang dapat dilakukan fortifikasi atau suplementasi bila dalam bentuk tepung (Aini et al., 2012). Olahan jagung yang lain yaitu beras jagung instan dapat digunakan sebagai makanan pokok untuk mensubstitusi beras (Aini et al., 2011).

Salah satu masalah dalam pembuatan beras jagung instan dan tepung jagung oleh UD Annisa adalah keterbatasan peralatan pengolahan jagung menjadi produk pangan yang bernilai ekonomi tinggi. Pengeringan dilakukan secara alami menggunakan sinar matahari. Proses pengeringan secara alami memang hemat bahan bakar, akan tetapi kelemahannya tergantung cuaca maka tidak bisa diperkirakan waktu pengeringan. Pengeringan menggunakan sinar matahari juga dapat menurunkan kualitas produk karena sulit mengatur kadar air yang diharapkan. Produk yang dikeringkan dengan cuaca yang tidak menentu juga rawan mengakibatkan tumbuhnya jamur atau kontaminan lain [4]. 
Permasalahan lain yang dihadapi dalam pembuatan tepung jagung dan beras jagung instan adalah pengayakan. Selama ini pengayakan masih menggunakan cara manual yaitu menggunakan tenaga manusia. Hal ini tentu membatasi kapasitas produksi, padahal permintaan kue-kue dari tepung jagung cukup tinggi.

UD Annisa juga memproduksi getas, kue kering semacam widaran yang terbuat dari tepung jagung kemudian diolah dengan metode penggorengan. Permasalahan dalam pembuatan getas adalah kapasitas produksi rendah, padahal permintaan sangat tinggi. Selama ini pencetakan getas dilakukan secara manual seperti terlihat pada Gambar 1 .

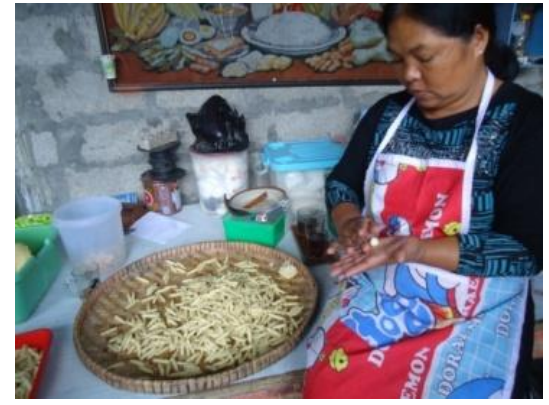

Gambar 1. Proses pencetakan getas jagung di UD Annisa

Program Hi-Link ditujukan untuk penerapan teknologi pengolahan pangan berbasis jagung yang dibutuhkan oleh industri, terutama untuk menerapkan penggunaan kabinet pengering dan ayakan getar (siever shaker). Peningkatan kuantitas dan kualitas produk mitra ini juga bertujuan meningkatkan daya saing UKM, tidak hanya di dalam negeri saja tetapi juga mampu bersaing di pasar bebas MEA (Masyarakat Ekonomi ASEAN).

\section{TARGET DAN LUARAN}

Kegiatan pengabdian kepada masyarakat HiLink ini mengambil mitra UD Annisa, UKM di Wonosobo yang bergerak di bidang usaha olahan jagung. Produk yang dihasilkan secara rutin oleh UD Annisa adalah beras jagung instan, tepung jagung, egg roll, dan getas jagung. Program Hi-Link dilaksanakan dengan mengintroduksi teknologi yang telah diperoleh dari hasil-hasil penelitian tim sesuai dengan permasalahan, kebutuhan, dan rencana program pemerintah daerah dan industry mitra yang telah teridentifikasi.

\section{Target}

Target kegiatan pengabdian kepada masyarakat ini secara umum adalah terlaksananya penerapan teknologi hasil penelitian yang dibutuhkan industri dan masyarakat, khususnya bagi UD Annisa di Wonosobo. Target khusus kegiatan IbM ini adalah:
1) Memperbaiki teknik pengeringan pada pembuatan beras jagung instan dan tepung jagung untuk menghindari kerugian karena kehilangan produk saat musim hujan.

2) Meningkatkan kapasitas produksi beras jagung instan dan tepung jagung dengan perbaikan teknik pengayakan.

3) Meningkatkan kapasitas produksi getas jagung.

\section{Luaran}

Luaran yang dihasilkan dari kegiatan adalah sebagai berikut:

1) Pengering kabinet untuk mengeringkan beras jagung instan dan tepung jagung terutama saat musim penghujan.

2) Ayakan getar untuk mempercepat proses pengayakan

3) Ekstruder untuk mencetak getas jagung

4) Produksi beras jagung instan dan tepung jagung dilakukan secara kontinyu

\section{METODE PELAKSANAAN}

Bahan utama yang digunakan adalah jagung. Peralatan yang diintroduksikan adalah pengering kabinet, ayakan getar (siever shaker) dan ekstruder sebagai pencetak getas. Pengering kabinet yang digunakan menggunakan sumber panas dari listrik dan gas. Meskipun demikian, saat listrik mati dapat digunakan generator.

Spesifikasi kabinet pengering adalah sebagai berikut : ukuran 1100 × 600 × $1800 \mathrm{~mm}$, kapasitas $25 \mathrm{~kg}$ bahan baku, bahan mild steell plate t1.2 mm, frame mild steel plate (bending profil), kecepatan pengeringan 0,6 sampai $1 \%$ per jam, accesories rack dari Galvalum, sistem welding, pintu type swing, blower (sirkulasi), temperature control (tipe analog), dan panel box (Gambar 2).

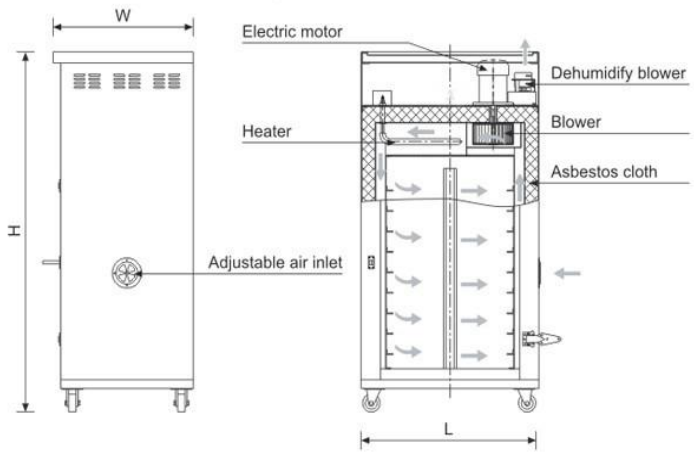

Gambar 2 Desain alat pengering kabinet yang diintroduksikan

Spesifikasi ayakan getar adalah sebagai berikut: ukuran 500 x $400 \mathrm{~mm}$ (diameter x tinggi), kapasitas tergantung bahan, bahan baku frame mild steel plate 
(bending profil), 2 stack (Material Stainless SUS 430), range oscilator $15 \mathrm{~mm}$, frekuensi oscilator 0 $\sim 150$, mode of oscilator : orbital/rotator, konsumsi daya $220 \mathrm{Vac} / 1 \mathrm{ph} / 50 / 60 \mathrm{~Hz} / 1 / 2 \mathrm{pk}$, asesoris guide clamper ( single stack) dan sistem knock down.

Ekstruder yang digunakan memiliki spesifikasi sebagai berikut: penggerak motor 1 pk /1400 $\mathrm{rpm} / 50 / 60 \mathrm{~Hz}$, pemasukkan dari corong atas /output dari depan, diameter die $6 \mathrm{~mm}$, frame dari mild steell, body dari stainless steel plate thk $1.2 \mathrm{~mm}$, model screw type, cutting unit, genset minimum Daya 2200 Watt, gear Reducer unit ratio 1 : 50 dan panel box untuk Genset .

Pengumpulan data dilakukan dengan cara menghitung kapasitas produksi sebelum dan sesudah adanya introduksi alat. Analisa data dilakukan secara deskriptif.

\section{HASIL DAN PEMBAHASAN}

\section{Pengeringan}

Pengeringan merupakan salah satu cara pengawetan pangan dengan penurunan kadar air bahan sampai mencapai kadar air tertentu yang dikehendaki sehingga bahan tersebut memiliki daya simpan lebih lama dan mempertahankan mutunya. Dasar pengeringan adalah terjadinya penguapan air ke udara karena perbedaan kandungan uap air antara udara dengan bahan yang dikeringkan. Kemampuan udara membawa uap air bertambah besar jika perbedaan antara kelembaban nisbi udara pengering dengan udara sekitar bahan semakin besar. Salah satu faktor yang mempercepat proses pengeringan adalah kecepatan angin atau udara yang mengalir. Udara yang tidak mengalir menyebabkan kandungan uap air di sekitar bahan yang dikeringkan semakin jenuh sehingga pengeringan semakin lambat.

Pada awalnya, proses pengeringan di UD Annisa dilakukan menggunakan teknik alami yaitu pengeringan sinar matahari. Ada beberapa kendala dalam mengeringkan tepung jagung dan beras jagung insan, terutama pada saat musi, penghujan, yang menurunkan kualitas dan kuantitas produksi, Pengeringan secara mekanis menggunakan alat pengering buatan (artificial dryer) dapat mempermudah dalam mengontrol faktor-faktor dalam proses pengeringan [5]. Salah satu pengering buatan yang bisa diintroduksikan ke UKM adalah pengering kabinet (cabinet dryer) (Gambar 3). Introduksi kabinet pengering agar pengeringan beras jagung instan dan tepung jagung tidak tergantung cuaca. Dengan menggunakan cabinet pengering, produksi beras jagung instan dan tepung jagung dapat dilakukan setiap hari, tidak tergantung cuaca dan dapat memprediksi waktu pengeringan sehingga kapasitas produksi akan meningkat. Penggunaan pengering kabinet juga meningkatkan kualitas karena kadar air dapat diseragamkan dan dapat menghindarkan terjadinya kontaminasi karena pertumbuhan mikroba.

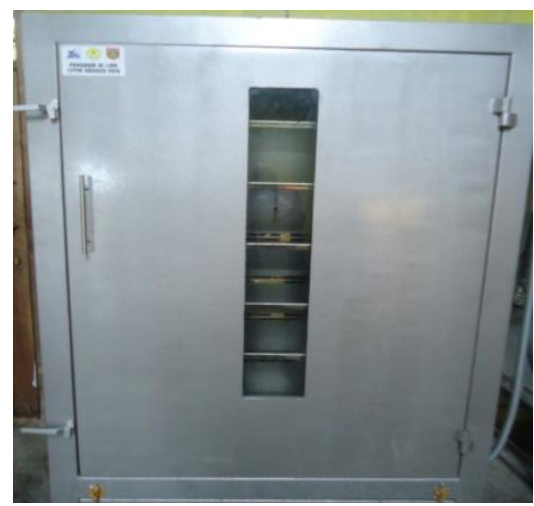

Gambar 3. Pengering kabinet yang diintroduksikan ke UD Annisa

Penggunaan pengering kabinet ini memiliki kelebihan dibandingkan pengeringan menggunakan sinar matahari sebagaimana terlihat pada Tabel 1 .

TABEL 1.

PERBEDAAN PENGERINGAN MENGGUNAKAN PENGERING KABINET DAN PENGERING MATAHARI

\begin{tabular}{|c|c|c|}
\hline Indikator & $\begin{array}{l}\text { Pengering kabinet } \\
\text { (cabinet dryer) }\end{array}$ & $\begin{array}{c}\text { Pengering } \\
\text { matahari (sun } \\
\text { dryer) }\end{array}$ \\
\hline $\begin{array}{l}\text { Waktu } \\
\text { pengeringan }\end{array}$ & $8-10$ jam & $\begin{array}{l}\text { Tidak tentu, } \\
\text { tergantung } \\
\text { cuaca }\end{array}$ \\
\hline $\begin{array}{l}\text { Suhu } \\
\text { pengeringan }\end{array}$ & $40-50{ }^{\circ} \mathrm{C}$ & Tidak tetap \\
\hline Perubahan & $\begin{array}{l}\text { Terjadinya } \\
\text { perubahan } \\
\text { enzimatis atau } \\
\text { fermentasi yang } \\
\text { merusak bahan } \\
\text { lebih singkat }\end{array}$ & $\begin{array}{l}\text { Terjadinya } \\
\text { pencoklatan } \\
\text { enzimatis }\end{array}$ \\
\hline Sanitasi & $\begin{array}{l}\text { Kebersihan produk } \\
\text { dapat dijaga }\end{array}$ & $\begin{array}{l}\text { Kemungkinan } \\
\text { adanya } \\
\text { kontaminasi } \\
\text { (debu, kotoran, } \\
\text { dll) }\end{array}$ \\
\hline $\begin{array}{l}\text { Perubahan } \\
\text { flavor }\end{array}$ & $\begin{array}{l}\text { Perubahan flavor } \\
\text { bisa diminimalkan }\end{array}$ & $\begin{array}{l}\text { Hilangnya } \\
\text { flavor mudah } \\
\text { menguap }\end{array}$ \\
\hline
\end{tabular}

Dengan adanya pengering buatan yang telah diintroduksikan tersebut dapat mengurangi salah satu permasalahan mitra yaitu terkendalanya produksi saat musim penghujan dan dapat menigkatkan kuantitas dan kualitas produksi tepung jagung serta beras jagung instan. 


\section{Pengayakan mekanis}

Pengayakan adalah cara pengelompokan butiran, yang akan dipisahkan menjadi satu atau beberapa kelompok [1]. Dengan demikian, dapat dipisahkan antara partikel lolos ayakan (butir halus) dan yang tertinggal diayakan (butir kasar). Ukuran butiran tertentu yang masih bisa melintasi ayakan, dinyatakan sebagai butiran batas. Proses pemisahan didasari atas perbedaan ukuran partikel didalam campuran tersebut. Sehingga ayakan memiliki ukuran pori atau lubang tertentu, ukuran pori dinyatakan dalam satuan mesh.

Pengayakan merupakan bagian penting dari setiap proses, terutama untuk menghasilkan produk yang berkualitas. Pengayak dapat digunakan untuk menghilangkan kontaminasi untuk memastikan bahwa bahan-bahan dan produk jadi memiliki kualitas terjamin selama produksi dan sebelum penggunaan atau pengiriman. Namun, desain peralatan pengayak telah mengalami perubahan radikal dalam beberapa tahun terakhir untuk memenuhi tuntutan baru dari perusahaan manufaktur farmasi. Tuntutan tersebut, termasuk meningkatkan produktivitas dan kualitas produk

Ukuran partikel penting dalam evaluasi kualitas tepung, sifat tepung dalam pengolahan dan kenampakan produk-produk yang diproses dengan cara pemanggangan. Metode analisis ukuran partikel dibagi menjadi 6 kelompok yaitu (1) metode visual (misalnya dengan mikroskop optik dan mikroskop elektron); (2) metode pemisahan (misalnya pengayakan); (3) Metode scanning stream; (4) metode scanning field (misalnya dengan fifraksi laser; (5) metode pengendapan; dan (6) metode permukaan (misalnya permeabilitas, adsorbsi) (Shekunov et al., 2007). Diantara metode-metode tesebut, metode pengayakan paling sering digunakan untuk mengkarakterisasi ukuran tepung dalam proses penggilingan. Menurut [7], tepung diayak melewati ayakan dengan bukaan $136 \mu \mathrm{m}$. Sedangkan di Amerika Utara, tepung pada umumnya harus melewati ayakan dengan ukuran bukaan $112 \mu \mathrm{m}$, dressed flour $132 \mu \mathrm{m}$ dan tepung kue $93 \mu \mathrm{m}$.

Pada tahap ini juga diintroduksikan alat pengayak bergetar untuk memisahkan produk berdasar ukuran partikel, terutama untuk nasi jagung instan dan tepung jagung (Gambar 3). Pengayakan secara mekanik (pengayak getaran, guncangan atau kocokan) dilakukan dengan bantuan mesin, yang umumnya mempunyai satu set ayakan dengan ukuran lebar lubang standar yang berlainan [6]. Bahan yang diayak, bergerak-gerak diatas ayakan, berdesakan melalui lubang kemudian terbagi menjadi fraksi-fraksi yang berbeda. Beberapa mesin pengayak bekerja dengan gerakan melingkar atau ellipsoid terhadap permukaan ayakan. Pada jenis ayakan yang statis, bahan yang diayak dipaksa melalui lubang dengan menggunakan bantuan udara kencang atau juga air deras

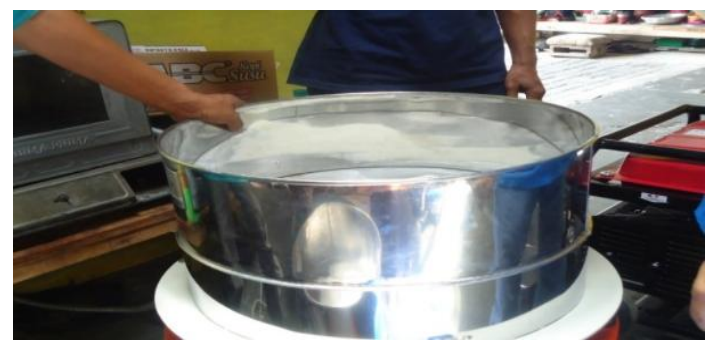

Gambar 3. Praktek pengayakan tepung jagung oleh UD Annisa menggunakan ayakan getar dari program Hi-Link

\section{Penggunaan ekstruder untuk pembuatan getas jagung}

Getas jagung merupakan makanan yang dibuat dari jagung dan bahan-bahan tambahan lain yaitu mentega, kelapa, telur, dan sebagainya. Pada tahap ini dilakukan perbaikan resep menggunakan formula getas yang dimodifikasi. Formula getas awal UD Annisa menggunakan kelapa parut dalam jumlah cukup banyak untuk menghasilkan rasa gurih yang khas, namun hal tersebut mengakibatkan produk mengandung lemak cukup tinggi sehingga cepat mengalami penurunan mutu karena ketengikan. Substitusi ampas kelapa dengan tepung ampas kelapa berkadar lemak rendah pada pembuatan getas jagung dapat mengurangi kadar kadar lemak produk tanpa mengurangi cita rasa gurih khas kelapa. Untuk meningkatkan kerenyahan produk ditambahkan tapioka (pati ubi kayu) sejumlah $7-10$ persen terhadap total tepung yang digunakan [8].

Proses pengolahan getas jagung adalah sebagai berikut:

- Jagung pipil disosoh kemudian direndam selama 3 hari agar terjadi fermentasi spontan.

- Selesai perendaman, jagung dicuci bersih dan digiling serta diayak, kemudian dikukus selama 5-10 menit kemudian didinginkan

- Tahap berikutnya adalah pengayakan sampai didapat butiran dengan ukuran homogen. Tepung jagung dicampur dengan terigu, dan tapioka dan diaduk hingga homogen. Penambahan tapioca bertujuan untuk mendapatkan tekstur renyah dan tidak mudah melempem. Dilakukan juga penambahan parutan kelapa dan diaduk hingga rata, dan ditambahkan mentega yang telah dicairkan dan air. Adonan diuleni (kneading) hingga terbentuk adonan yang plastis atau mudah dicetak.

- Pencetakan secara manual menjadi bentuk oval memanjang $( \pm 2 \mathrm{~cm} ; \boldsymbol{Q}=0,5 \mathrm{~cm})$.

- Adonan yang telah dicetak selanjutnya digoreng hingga matang 
- Sementara itu, dipersiapkan bahan untuk melapis (enrobing) yaitu gula pasir, dilarutkan dengan sedikit air. Setelah mengental, getas dimasukkan dan diaduk hingga merata, kemudian didinginkan dan dikemas.

Untuk mempercepat pencetakan getas juga diintroduksikan ekstruder untuk mencetak getas agar bentuk dan ukuran yang dihasilkan seragam serta kapasitas produksi meningkat (Gambar 4). Introduksi ekstruder dapat meningkatkan kualitas dan kuantitas produk.

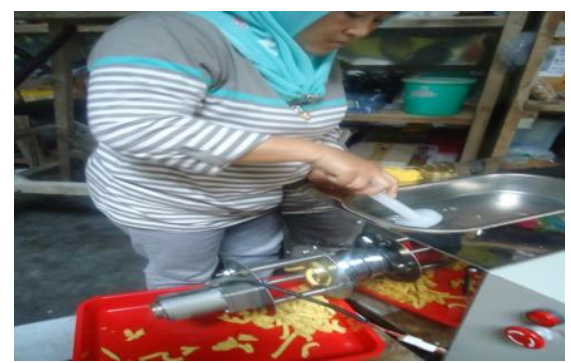

Gambar 4. Praktek pencetakan getas oleh pemilik UD Annisa menggunakan ekstruder

Introduksi ekstruder untuk mencetak getas memberikan banyak keuntungan bagi mitra, yaitu:

- Prosesnya mudah dan cepat

- Fleksibel, dapat disesuaikan bahan baku, produk dan kondisi operasinya

- Biaya rendah dan produktivitas tinggi karena dapat beroperasi secara kontinyu

- Waktu singkat sehingga nutrisi dapat dipertahankan

- Kerusakan gizi minimal, antinutrisi rusak

Kegiatan Hi-Link ini telah meningkatkan kuantitas produksi mitra yaitu UD Annisa seperti tercantum pada Tabel 2. Keberlanjutan kegiatan ini akan lebih meningkatkan kemampuan UD Annisa dalam meningkatkan kesejahteraan, baik diri sendiri maupun masyarakat sekitar.

\section{TABEL 2}

KAPASITAS PRODUKSI INDUSTRI MITRA SEBELUM DAN SETELAH ADANYA KEGIATAN HILINK

\begin{tabular}{lccc}
\hline Produk & \multicolumn{2}{c}{ Produksi (kg/bulan) } & \\
& $\begin{array}{l}\text { Sebelum } \\
\text { kegiatan Hi Link }\end{array}$ & $\begin{array}{l}\text { Sesudah } \\
\text { kegiatan } \\
\text { Link }\end{array}$ & Hi \\
\hline Beras jagung & 150 & 300 & \\
instan & & 200 \\
Tepung jagung & 50 & 400 \\
Getas jagung & 150 & \\
\hline
\end{tabular}

\section{KESIMPULAN}

Kegiatan Hi Link memberikan dampak positif pada meningkatnya kapasitas produksi karena adanya introduksi peralatan berupa pengering kabinet, ayakan getar dan ekstruder. Peningkatan kapasitas produksi yaitu beras jagung instan dari 150 menjadi $300 \mathrm{~kg}$ per bulan, tepung jagung dari $50 \mathrm{~kg}$ menjadi $200 \mathrm{~kg}$ per bulan dan getas jagung dari 150 $\mathrm{kg}$ menjadi $400 \mathrm{~kg}$ per bulan.

\section{UCAPAN TERIMA KASIH}

Penulis mengucapkan terima kasih Kepada Direktorat Riset dan Pengabdian Masyarakat, Kementerian Riset, Teknologi dan Pendidikan Tinggi yang telah memberikan dana melalui Program Hi Link 2018 dengan nomer kontrak 2035/UN23.14/PM/2018

\section{DAFTAR PUSTAKA}

[1] N. Aini, P. Hariyadi, T.-R. Muchtadi, and N. Andarwulan, "Hubungan antara waktu fermentasi grits jagung dengan sifat gelatinisasi tepung jagung putih yang dipengaruhi ukuran partikel," J. Teknol. dan Ind. Pangan, vol. XXI, no. 1, pp. 2824, 2010.

[2] N. Aini, V. Prihananto, and S. J. Munarso, "Characteristics of white corn noodle substitued by tempeh flour," J. Teknol. dan Ind. Pangan, vol. XXIII, no. 2, pp. 179-185, 2012.

[3] N. Aini, V. Prihananto, and S. J. Munarso, "Nutritional And Sensory Value Of Corn Rice Instant Influenced By Corn Immersion And Tempeh Substitution," Agroteknologi, vol. 5, no. 2, pp. 108-126, 2011.

[4] C. Borchani, S. Besbes, M. Masmoudi, M. A. Bouaziz, C. Blecker, and H. Attia, "Influence of Oven-Drying Temperature on Physicochemical and Functional Properties of Date Fibre Concentrates," Food Bioprocess Technol., vol. 5, no. 5, pp. 1541-1551, Jul. 2012.

[5] P. P. Lewicki, "Effect of pre- drying treatment, drying and rehydration on plant tissue properties: A review," Int. J. Food Prop., vol. 1, no. 1, pp. 1-22, Jan. 1998.

[6] B. Y. Shekunov, P. Chattopadhyay, H. H. Y. Tong, and A. H. L. Chow, "Particle Size Analysis in Pharmaceutics: Principles, Methods and Applications," Pharm. Res., vol. 24, no. 2, pp. 203-227, Feb. 2007.

[7] J. A. Gwirtz and M. N. Garcia-Casal, "Processing maize flour and corn meal food products," Ann. N. Y. Acad. Sci., vol. 1312, no. 1, pp. 66-75, Apr. 2014.

[8] R. Latifa, M. Riana, N. Aini, and H. Dwiyanti, "Formulasi dan optimasi flakes kaya serat berbasis pati garut resisten tipe III menggunakan Response Surface Methodology," J. Litbang Provinsi Jawa Teng., vol. 13, no. 2, pp. 193-202, 2015.

[9] N. Aini, G. Wijonarko, and B. Sustriawan, "Physical, Chemical, and Functional Properties of Corn Flour Processed by Fermentation," Agritech, vol. 36, no. 2, pp. 160-169, 2016.

[10] M.-L. Yuan, Z.-H. Lu, Y.-Q. Cheng, and L.-T. Li, "Effect of spontaneous fermentation on the physical properties of corn starch and rheological characteristics of corn starch noodle," $J$. Food Eng., vol. 85, no. 1, pp. 12-17, 2008.

[11]E. M. Grajales-García, P. Osorio-Díaz, I. Goñi, D. HervertHernández, S. H. Guzmán-Maldonado, and L. A. Bello-Pérez, "Chemical Composition, Starch Digestibility and Antioxidant Capacity of Tortilla Made with a Blend of Quality Protein Maize and Black Bean," Int. J. Mol. Sci., vol. 13, no. 12, pp. 286-301, Dec. 2011.

[12]D. P. Margaris and A.-G. Ghiaus, "Dried product quality improvement by air flow manipulation in tray dryers," $J$. Food Eng., vol. 75, no. 4, pp. 542-550, Aug. 2006.

[13]H. Darabi, A. Zomorodian, M. H. Akbari, and A. N. Lorestani, "Design a cabinet dryer with two geometric configurations using CFD," J. Food Sci. Technol., vol. 52, no. 1, pp. 359366, Jan. 2015. 